THE

\title{
HISTORICAL COLLECTIONS
}

\author{
" \\ A CITIZEN OF LONDON \\ IN THE FIFTEENTH CENTURY.
}

CONTAINING:

I. JOHN PAGE'S POEM ON THE SIEGE OF ROUEN.

II. LYDGATE'S VERSES ON THE KINGS OF ENGLAND.

III. WILLIAM GREGORY'S CHRONICLE OF LONDON.
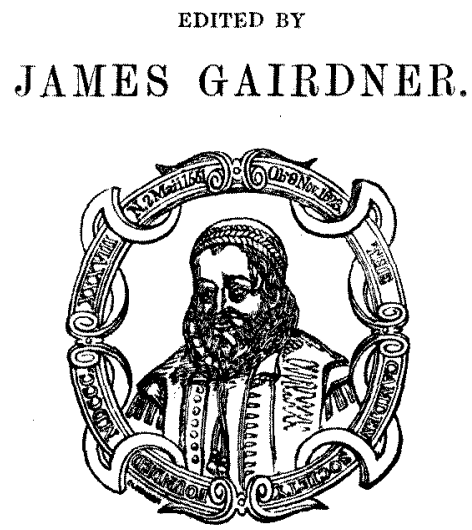

PRINTED FOR THE CAMDEN SOCIETY.

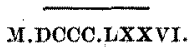


WESTMINSTER :

PRINTED BY NICHOLS AND SONS,

25 , PARLIAMENT STREET.

[NEW SERIES XVII.] 


\title{
COUNCIL OF TIIE CAMDEN SOCIETY \\ FOR THE YEAR 1876-77.
}

\author{
Presidont, \\ THE RIGH'T HON. THE EARL OF VERULAM, F.R.G.S. \\ WILLIAM CHAPPELL, ESQ. F.S.A., Treasur \\ HENRY CHARLES COOTK, ESQ. F.S.A. \\ JAMES GAIRDNER, ESQ. \\ SAMUEL RAWSON GARDINER, ESQ., Director. \\ WILLIAM OXENHAM HEWLETT, ESQ. \\ ALFRED KINGSTON, ESQ., Seoretary. \\ SIR JOHN MACLEAN, F.S.A. \\ FREDERIC OUVRY, ESQ. V.P. S.A. \\ THE EARL OE POWIS, LL.D. \\ JAMES ORCHARD PHILLIPPS, FSQ, F.R.S., F.S.A. \\ EVELYN PHILIP SHIRLEY, ESQ., M.A. \\ REV. W. SPARROW SIMPSON, D.D. F.S.A. \\ JAMES SPEDDING, ESQ. \\ WILLIAM JOHN THOMS, ESQ. F.S.A. \\ J. R. DANIEL-TYSSEN, ESQ. F.S.A.
}


The Council of the Camden Societry desire it to be understood that they are not answerable for any opinions or observations that may appear in the Society's publications; the Editors of the several Works being alone responsible for the same. 